\title{
CURRENT
}

Jurnal Kajian Akuntansi dan Bisnis Terkini

https://current.ejournal.unri.ac.id

\section{PENGELOLAAN KEUANGAN DESA PADA DESA-DESA DI KABUPATEN KAMPAR}

\author{
Daniatul Izzah $^{1^{*}}$, Taufeni Taufik ${ }^{2}$, Vera Oktari ${ }^{3}$ \\ Program Studi Akuntansi, Fakultas Ekonomi dan Bisnis, Universitas Riau, Pekanbaru \\ *E-mail: izzahdaniatul@gmail.com
}

\section{Keywords \\ Communitiy Participation, \\ Transparency, \\ Accountability, Quality \\ Of Human Resources, \\ Utilization Of Information \\ Technology, The \\ Implementation of \\ Internal Control Systems, \\ Village Financial \\ Management}

\section{Article informations}

Received:

2021-02-07

Accepted:

2021-02-29

Available Online:

2021-03-26

\begin{abstract}
This study aims to determine the effect of community participation, transparency, accountability, quality of human resources, utilization of information technology and the implementation of internal control system on village financial management. This research was conducted in the village of Kampar Regency. The population in this study were village officials who worked at the village office in Kampar District, amounting to 242 villages. This study used purposive sampling. The number of samples in this study were 150 respondents, from each village 5 respondents would be taken with the criteria of the Village Head, Village Secretary, Head of Finance, Section Chief and BPD. The test was carried out using SPSS 25.0 for Windows and Microsoft Excel 2010. The analysis technique in this study uses multiple regression analysis. The results of this study indicate that: (1) Community participation influences the effectiveness of village financial management; (2)Transparency influences the effectiveness of village financial management; (3) Accountability influences the effectiveness of village financial management; (4) The quality of human resources influences the effectiveness of village financial management; (5) The use of information technology influences the effectiveness of village financial management; (6) The application of an internal control system influences the effectiveness of village financial management.
\end{abstract}

\section{PENDAHULUAN}

Desa diberikan kesempatan yang cukup besar untuk mengurus pemerintahannya serta pelaksanaan pembangunannya untuk meningkatkan taraf kesejahteraan dan kualitas hidup masyarakat desa, sesuai dengan UU Nomor 6 Tahun 2014 tentang Desa. Pada tahun 2018, dana desa yang diberikan dari pemerintah pusat adalah senilai 60 triliun rupiah yang diperuntukkan kepada 74.903 desa yang ada di seluruh Indonesia (www.dpjk.kemenkeu.go.id). Dengan jumlah dana desa yang besar yang ditransfer pemerintah pusat artinya tanggung jawab pemerintah desa sangat besar dalam melakukan pengelolaan keuangan desa. Namun salah satu faktor yang menghambat keberhasilan program 
tersebut adalah terjadinya penyimpangan dalam pengelolaannya (Hartati, 2020). Seperti yang disebutkan oleh Indonesia Corruption Watch (ICW) dari tahun 2015 hingga semester I 2018, kasus penyelewengan dana desa mengalami peningkatan dari tahun ke tahun, dimana sudah tercatat sebanyak 181 kasus korupsi dana desa dengan 184 tersangka korupsi dengan angka kecurangan $\operatorname{Rp} 40,6$ miliar.

Salah satu permasalahan penyelewengan dana desa di Provinsi Riau yaitu di Kabupaten Kampar, dimana berdasarkan Laporan Hasil Pemeriksaan BPK Kabupaten Kampar Tahun 2015 Nomor 11.C/LHP/XVIII.PEK/2016, terdapat belanja transfer pada Bantuan Dana Desa yang belum dipertanggungjawabkan. Selain itu, pada tahun 2017 terdapat permasalahan terkait desa yang belum menyampaikan laporan realisasi APBDes. Berdasarkan laporan hasil pemeriksaan BPK Kabupaten Kampar Tahun 2017 Nomor 21.CL/LHP/XVIII.PEK/05/2018, delapan desa belum menyampaikan Laporan Realisasi APBDes. Berdasarkan situasi di atas dapat dilihat adanya indikasi terjadinya masalah dalam pengelolaan keuangan desa yang tidak berjalan dengan baik (www.dpjk.kemenkeu.go.id).

Berdasarkan Permendagri Nomor 20 Tahun 2018, penyelenggaraan pemerintahan desa yang baik pengelolaan keuangan desa memerlukan sistem akuntabilitas, transparansi serta melibatkan partisipasi masyarakat. Selain itu, Wardani \& Andriyani (2017) mengatakan bahwa ada tiga sumber yang mempengaruhi keandalan dan ketepatan waktu laporan keuangan desa yaitu sumber daya manusia yang kompeten, dukungan sarana teknologi informasi yang memadai, dan sistem pengendalian intern yang baik. Sumber daya yang berkualitas harus didukung dengan latar belakang pendidikan akuntansi, sering mengikuti pelatihan, seminar dan mempunyai pengalaman di bidang keuangan (Sembiring, 2013).

Sumber daya yamg berkualitas harus didukung dengan latar belakang pendidikan akuntansi, sering mengikuti pelatihan/seminar, dan mempunyai pengalaman di bidang keuangan (Sembiring, 2013). Yosefrinaldi (2013) mengatakan bahwa semakin besar pemanfaatan teknologi informasi maka kualitas laporan keuangan yang dihasilkan pemerintah juga akan semakin baik. Dengan adanya sistem pengendalian intern yang baik diharapkan mampu mencegah terjadinya kesalahan dalam proses akuntansi sehingga proses akuntansi dapat dikerjakan dengan cepat dan tepat serta dapat meyakinkan masyarakat desa tentang keakuratan, keandalan, dan ketepatwaktuan laporan keuangan pemerintah desa. Dengan adanya sistem pengendalian intern yang baik diharapkan mampu mencegah atau mendeteksi terjadinya kesalahan dalam proses akuntansi sehingga proses akuntansi dapat dikerjakan dengan cepat dan tepat serta dapat meyakinkan masyarakat desa tentang keakuratan, keandalan, dan ketepatwaktuan laporan keuangan pemerintah desa. Taufik (2019) 
mengatakan penerapan sistem pengendalian internal yang efektif sangat berguna dalam mencegah dan mempersulit penipuan.

Penelitian yamg dilakukan oleh Wardani \& Andriyani (2017) menunjukkan bahwa kualitas sumber daya manusia dan sistem pengendalian intern berpengaruh secara signifikan terhadap keandalan laporan keuangan pemerintah desa. Sementara itu, pemanfaatan teknologi informasi tidak berpengaruh secara signifikan terhadap keandalan pelaporan keuangan pemerintahan desa. Namun, berbeda dengan penelitian yang dilakukan oleh Widyatama et al. (2017) kompetensi aparatur dari pemerintah desa secara signifikan tidak memengaruhi akuntabilitas pengelolaan keuangan Alokasi Dana Desa (ADD). Dalam penelitian Sugista (2017) yang dilakukan di desa-desa Kabupaten Lampung Selatan menunjukkan bahwa semakin tinggi tingkat pertisipasi masyarakat dalam pengelolaan keuangan pemerintahan desa dapat meningkatkan pembangunan desa. Hal ini menunjukkan bahwa masyarakat berperan aktif dalam pengelolaan keuangan desa sehingga dapat mengontrol pembangunan desa.

Selain itu penelitian Medianti (2018) menunjukkan bahwa partisipasi masyarakat desa-desa di Kabupaten Bintan berpengaruh terhadap pengelolaan dana desa. Artinya semakin intens partisipasi masyarakat, maka pengelolaan dana desa semakin akuntabel. Berbeda dengan hasil penelitian dari Manopo (2013) dimana pertanggungjawaban pengelolaan keuangan desa masih sebatas pertanggungjawaban fisik saja, dan kendala utama dalam pertanggungjawaban administrasi keuangan adalah kompetensi SDM sehingga masih memerlukan pendampingan dari aparat pemerintah daerah. Sejalan dengan penelitian Machfiroh (2019) menyatakan bahwa pengelolaan keuangan desa di Desa Benua Tengah yakni dari tahap perencanaan, pelaksanaan, penatausahaan, pelaporan dan pertanggungjawaban menunjukkan sudah dikelola secara akuntabel.

Penelitian ini merupakan replikasi dari penelitian yang dilakukan oleh Situmorang (2018). Perbedaan penelitian ini dengan sebelumnya terletak pada objek penelitian dan variabel. Objek penelitian ini adalah perangkat desa di Kabupaten Kampar berbeda dengan Situmorang (2018) yaitu perangkat desa di Kabupaten Rokan Hulu, sedangkan penelitian ini menambahkan variabel partisipasi masyarakat, sumber daya manusia, pemanfaatan tekonologi informasi dan penerapan sistem pengendalian intern desa. Alasan menambahkan variabel ini yaitu meningkatkan pengelolaan keuangan desa dengan menerapkan asas-asas pengelolaan keuangan desa secara baik mulai dari tahap perencanaan, pelaksanaan, penatausahaan dan pelaporan/pertanggungjawaban di desa-desa pada Kabupaten Kampar. 


\section{PENGEMBANGAN HIPOTESIS}

\section{Pengaruh Partisipasi Masyarakat Terhadap Pengelolaan Keuangan Desa}

Pengelolaan keuangan pemerintahan desa yang baik dikelola berdasarkan praktikpraktik pemerintahan dan asas-asas yang tertuang di dalam Permendagri No. 20 Tahun 2018 yaitu salah satunya partisipatif. Partisipatif yang dimaksud adalah penyelenggaraan pemerintahan desa yang mengikutsertakan kelembagaan desa dan unsur masyarakat.

Berdasarkan Peraturan Bupati Kampar Nomor 16 Tahun 2017 menyebutkan bahwa partisipatif dalam kegiatan pengelolaan dana desa direncanakan, dilaksanakan dan dievaluasi dengan melibatkan seluruh unsur masyarakat desa dapat meningkatkan pelaksanaan penyelenggaraan pemerintahan desa dalam rangka mendukung lembaga kemasyarakatan desa dalam perencanaan, pelaksanaan dan pengendalian pembangunan secara partisipasif sesuai dengan potensi di desa. Semakin tinggi partisipasi maka pelaksanaan kegiatan yang menyangkut kebutuhan masyarakat yang merupakan hasil dari pengelolaan dana desa yang baik. Hal ini dapat dilihat dari penelitian Medianti (2018) menunjukkan bahwa partisipasi masyarakat berpengaruh terhadap pengelolaan dana desa. Artinya semakin intens partisipasi masyarakat, maka pengelolaan dana desa semakin akuntabel. Berdasarkan uraian tersebut, maka hipotesis pertama yang diajukan dalam penelitian ini adalah sebagai berikut.

\section{$\mathrm{H}_{1}$ : Partisipasi masyarakat berpengaruh terhadap pengelolaan keuangan desa.}

\section{Pengaruh Transparansi Terhadap Pengelolaan Keuangan Desa}

Transparansi adalah pemberian pelayanan publik yang harus bersifat dapat terbuka, mudah dan dapat diakses oleh semua pihak yang membutuhkan dan disediakan secara memadai serta mudah umtuk dimengerti (Mahmudi, 2015). Pengelolaan keuangan desa yang baik harus memenuhi unsur transparansi diantaranya informatif, keterbukaan, pengungkapan, ketersediaan informasi, keterlibatan masyarakat, keterbukaan proses, dan keterbukaan informasi. Hal ini dapat dibuktikan dalam peneltian (Rosyidi, 2018). Transparansi mempunyai pengaruh signifikan terhadap akuntabilitas pemerintah desa dalam pengelolaan alokasi dana desa di Kecamatan Salo. Artinya semakin tinggi tingkat transparansi maka semakin baik pemerintah desa dalam pengelolaan alokasi dana desa.

Selanjutnya penelitian dari Ramadan (2019) transparansi berpengaruh terhadap akuntabilitas pengelolaan keuangan desa. Penelitian Sukmawati \& Nurfitriani (2019) dan Pratama (2018) menunjukkan bahwa transparansi berpengaruh dalam pengelolaan dana desa. Berdasarkam uraian tersebut, maka hipotesis yang dapat diajukan pada peneltian ini adalah sebagai berikut: 


\section{$\mathrm{H}_{2}$ : Transparansi berpengaruh terhadap pengelolaan keuangan desa.}

\section{Pengaruh Akuntabilitas Terhadap Pengelolaan Keuangan Desa}

Akuntability didefinisikan sebagai kewajiban pihak pemegamg amanah untuk dapat memberikam pertanggungjawaban, menyajikan laporan, mengungkapkan segala aktivitas dan kegiatan yang mejadi tanggung jawabmya kepada pihak pemberi amanah (Mardiasmo, 2009).

Dengan adanya akuntabilitas dalam pengelolaan keuangan desa merupakan pertanggungjawaban atas setiap pelaksanaan kegiatan pemerintah dan aparat desa tertib kepada masyarakat maupun jajaran pemerintah diatasnya sesuai perundangundangan. Hasil penelitian Nafidah \& Suryaningtyas (2016) bahwa akuntabilitas berpengaruh terhadap pengelolaan keuangan desa. Akuntabilitas dalam pengeloaan keuangan desa yang baik secara teknik dan administrasi sesuai dengan peraturan yang berlaku dapat meningkatkan pembangunan dan pemberdayaan masyarakat. Selain itu, penelitian yang dilakukan Dura (2016) bahwa akuntabilitas pengelolaan keuangan desa signifikan terhadap kesejahteraan masyarakat. Hipotesis ketiga yang diajukan pada penelitian ini adalah sebagai berikut:

\section{$\mathrm{H}_{3}$ : Akuntabilitas berpengaruh terhadap pengelolaan keuangan desa.}

\section{Pengaruh Kualitas Sumber Daya Manusia Terhadap Pengelolaan Keuangan Desa}

Menurut Pasolong (2013) mengemukakan bahwa kualitas sumber daya manusia yaitu tenaga kerja yang memiliki pengetahuan, keterampilan dan moral yang tinggi. Kemudian, kualitas sumber daya manusia menurut Arfianti (2011) yaitu kemampuan sumber daya manusia untuk melaksanakan tugas dan tanggung jawab yang diberikan kepadanya dengan bekal pendidikan, pelatihan, dan pengalaman yang cukup memadai. Sumber daya manusia mempunyai pengaruh yang besar dalam pengelolaan keuangan desa hal ini karena di dalam pemerintahan desa sumber daya manusia yang menjalankan dan menggerakkannya. Oleh karena itu, sumber daya manusia tersebut harus memiliki kemampuan, pengetahuan dan prilaku yang baik. Seperti yang dikatakan Sembiring (2013) sumber daya yang berkualitas harus didukung dengan latar belakang pendidikan akuntansi, sering mengikuti pendidikan atau pelatihan-pelatihan, dan mempunyai pengalaman di bidang keuangan. Sehingga pemerintah desa mampu menyajikan laporan keuangan yagg berkualitas sebagai bentuk pertanggungjawaban kinerjanya kepada masyarakat desa.

Dalam penelitian yang dilakukan oleh Wardani \& Andriyani (2017) menunjukan bahwa kualitas sumber daya manusia berpengaruh positif secara signifikan terhadap 
keandalan pelaporan keuangan pemerintahan desa. Berdasarkan uraian tersebut, maka hipotesis keempat yang diajukan dalam penelitiam ini adalah sebagai berikut:

\section{$\mathrm{H}_{4}$ : Kualitas sumber daya manusia berpengaruh terhadap pengelolaan keuangan desa.}

\section{Pengaruh Pemanfaatan Teknologi Informasi Terhadap Pengelolaan Keuangan Desa}

Teknologi informasi adalah segala bentuk teknologi yang diterapkan untuk memproses dan mengirimkan informasi dalam bentuk elektronis, mikro komputer, komputer mainframe (Rusman, 2011). Pemanfaatan teknologi informasi sangat berpengaruh dalam pengelolaan keuangan desa. Lebih lanjut Pramurdiarta (2015) menyatakan pemamfaatan teknologi informasi akan membantu sumber daya manusia dalam melakukan proses akuntansi dan dapat mengurangi resiko kesalahan dalam pemrosesan data, sehingga dapat menghasilkan laporan keuangan yang andal.

Aulia (2018) melakukan penelitian tentang pengelolaan dana desa menunjukkan bahwa pemafaatan teknologi informasi berpengaruh terhadap akuntabilitas pengelolaan dana desa. Selanjutnya Yosefrinaldi (2013) mengatakan bahwa semakin besar dan baik dalam pemanfaatan teknologi informasi maka kualitas laporan keuangan yang dihasilkan pemerintah akan semakin baik pula. Dengan adanya sistem pengendalian intern yang baik diharapkan mampu mencegah atau mendeteksi terjadinya kesalahan dalam proses akuntansi sehingga proses akuntansi dapat dikerjakan dengan cepat dan tepat serta dapat meyakinkan masyarakat desa tentang keakuratan, keandalan, dan ketepatwaktuan laporan keuangan pemerintah desa. Berdasarkan uraian tersebut, maka hipotesis kelima yang diajukan dalam penelitian ini adala sebagai berikut:

\section{$\mathrm{H}_{5}$ : Pemanfaatan teknologi informasi berpengaruh terhadap pengelolaan keuangan desa.}

\section{Pengaruh Penerapan Sistem Pengendalian Intern Terhadap Pengelolaan Keuangan Desa}

Sistem pengendalian internal adalah proses yang integral pada kegiatan atau tindakan yang dilakukan secara terus menerus oleh pimpinan dan tercapainya tujuan organisasi melalui kegiatan yang efektif dan efisien, keandalan pelaporan keuangan, pengamanan aset negara, serta ketaatan terhada peraturan perundang-undangan (Peraturan Pemerintah Nomor 60 Tahun 2014 Tentang Dana Desa yang Bersumber dari APBN, 2014). Sistem pengendalian intern sangat berpengaruh dalam pengelolaan keuangan desa karena bertujuan untuk memberi keyakinan yang memadai tentang salah satunya laporan keuangan yang dapat diandalkan. Hal ini dibuktikan oleh penelitian yang dilakukan oleh Marlinawati \& Wardani (2018) menunjukkan bahwa sistem pengendalian intern berpengaruh secara 
signifikan terhadap keandalan pelaporan keuangan pemerintah desa. Sama halnya dengan penelitian yag dilakukan oleh Widyatama et al. (2017) menunjukkan bahwa sistem pengendalian aparatur dari pemerintah desa secara signifikan mempengaruhi akuntabilitas pengelolaan keuangan Alokasi Dana Desa (ADD). Berdasarkan uraian diatas, maka hipotesis yang diajukan dalam penelitian ini adalah sebagai berikut:

\section{$\mathrm{H}_{6}$ : Penerapan sistem pengendalian intern berpengaruh terhadap pengelolaan keuangan desa.}

\section{METODE PENELITIAN}

\section{Populasi dan Sampel}

Populasi dalam penelitian ini adalah perangkat desa yang bekerja pada kantor desa di Kabupaten Kampar. Penelitian ini menggunakan purposive sampling. Jumlah sampel dalam penelitian ini adalah 150 responden, dari setiap desa akan diambil 5 responden dengan kriteria memiliki jabatan sebagai Kepala Desa, Sekretaris Desa, Kaur Keuangan, Kepala Seksi dan BPD.

\section{Teknik Pengumpulan Data}

Teknik pengumpulan data yang digunakan dalam penelitian ini adalah menggunakan sebaran kuesioner yang berisi pernyataan-pernyataan yang dibagi menjadi beberapa bagian dan merupakan kumpulan dari beberapa penelitian terdahulu.

\section{Metode Analisis Data}

Metode penelitian ini menggunakan variabel terikat (dependen) yaitu Pengelolaan Keuangan Desa dan variabel bebas (independen) yaitu Partisipasi Masyarakat, Transparansi, Akuntabilitas, Kualitas Sumber Daya Manusia, Pemanfaatan Teknologi Informasi dan Penerapan Sistem Pengendalian Intern. Penelitian ini mempunyai empat hipotesis yang diuji dengan menggunakan software SPSS (Statistical Product and Service Solution). Untuk menguji hipotesis 1 , hipotesis 2 , hipotesis 3 dan hipotesis 4 digunakan model analisis regresi berganda yang dirumuskan sebagai berikut:

$\mathrm{Y}=\alpha+\beta 1 \mathrm{X} 1+\beta 2 \mathrm{X} 2+\beta 3 \mathrm{X} 3+\beta 4 \mathrm{X} 4+\beta 5 \mathrm{X} 5+\beta 6 \mathrm{X} 6$

Dimana:

$\mathrm{Y}=$ Pengelolaan Keuangan Desa

$\alpha=$ Konstanta

$\beta=$ Besaran koefisien regresi dari masing-masing variable

$\mathrm{X} 1=$ Partisipasi Masyarakat 
$\mathrm{X} 2=$ Transparansi

$\mathrm{X} 3=$ Akuntabilitas

X4 = Kualitas Sumber Daya Manusia

$\mathrm{X} 5=$ Pemanfaatan Teknologi Informasi

X6 = Penerapan Sistem Pengendalian Intern

\section{HASIL PENELITIAN DAN PEMBAHASAN}

Hasil survei kuesioner dalam penelitian ini menunjukkan dari 150 kuesioner (100\%) yang telah disebarkan, kuesioner yang tidak direspon sebanyak 20 kuesioner (13,33\%), kuesioner yang direspon sebanyak kuesioner (86,66\%), kuesioner yang tidak dapat diolah sebanyak 0 kuesioner (0\%) dan kuesioner yang dapat diolah sebanyak 130 kuesioner $(86,66 \%)$.

\section{Hasil Uji Statistik Deskriptif}

Analisis ini digunakan untuk memberikan gambaran umum mengenai deskripsi variabel penelitian Pengelolaan Keuangan Desa yang disajikan dalam tabel yang menunjukkan angka minimum, maksimum, rata-rata, dan standar deviasi.

Tabel 1

Statistik Deskriptif

\begin{tabular}{lccccc}
\hline & N & Minimum & Maximum & Mean & Std. Deviation \\
\hline Total_X1 & 130 & 16 & 35 & 26,44 & 3,362 \\
Total_X2 & 130 & 19 & 30 & 24,79 & 2,948 \\
Total_X3 & 130 & 26 & 35 & 30,96 & 2,561 \\
Total_X4 & 130 & 30 & 45 & 37,59 & 4,049 \\
Total_X5 & 130 & 17 & 35 & 27,48 & 3,794 \\
Total_X6 & 130 & 90 & 120 & 103,08 & 7,726 \\
Total_Y & 130 & 104 & 140 & 124,32 & 10,108 \\
Valid N (listwise) & 130 & & & &
\end{tabular}

\section{Sumber: Data Olahan menggunakan SPSS}

Dari Tabel 1 dapat dilihat bahwa nilai rata-rata variabel partisipasi masyarakat (X1), transparansi (X2), akuntabilitas (X3), kualitas SDM (X4), pemanfaatan teknologi informasi (X5), penerapan SPI (X6) dan pengelolaan keuangan desa (Y) lebih besar daripada standar deviasinya. Hal ini menunjukkan bahwa variabel tersebut dapat berkontribusi dengan baik dan tidak menunjukkan bias. 


\section{Hasil Uji Validitas}

Uji validitas dilakukan dengan menghitung korelasi antara skor masing-masing pertanyaan dengan total skor pertanyaan. Dimana validitas data diukur dengan membandingkan $\mathrm{r}$ hitung dan $\mathrm{r}$ tabel, $\mathrm{r}$ tabel dapat dihitung dengan $\mathrm{df}=\mathrm{N}-2$. Jumlah responden dalam penelitian ini sebanyak 130 , sehingga $\mathrm{df}=130-2=128, \mathrm{r}(0,05 ; 128)=$ 0,1723. Jika $r_{\text {hitung }}>r_{\text {tabel }}$ maka pernyataan tersebut dinyatakan valid.

\section{Hasil Uji Validitas Variabel Pengelolaan Keuangan Desa}

Tabel 2

Hasil Uji Validitas

\begin{tabular}{cccc}
\hline Keterangan & r Hitung & r Tabel & Kesimpulan \\
\hline Y & $0,508-0,817$ & 0,1723 & Valid \\
X1 & $0,471-0,856$ & 0,1723 & Valid \\
X2 & $0,594-0,832$ & 0,1723 & Valid \\
X3 & $0,569-0,840$ & 0,1723 & Valid \\
X4 & $0,477-0,811$ & 0,1723 & Valid \\
X5 & $0,527-0,835$ & 0,1723 & Valid \\
X6 & $0,429-0,816$ & 0,1723 & Valid
\end{tabular}

Sumber: Data Olahan menggunakan SPSS

Dapat dilihat dari tabel di atas, bahwa nilai $r$ hitung > $r$ tabel yang artinya semua item pernyataan untuk variabel Penerapan Sistem Pengendalian Intern ini dapat dikatakan valid.

\section{Hasil Uji Reliabilitas}

Uji reliabilitas digunakan untuk mengukur suatu kuesioner yang merupakan indikator dari variabel (Ghozali, 2013). Suatu kuesioner dikatakan reliabel jika jawaban responden terhadap suatu pernyataan dalam kuesioner adalah konsisten atau stabil dari waktu ke waktu. Untuk mengukur reliabilitas dalam pengolahan data diliat pada Cronbach Alpha Reability Coefisien dengan signifikansi yang digunakan lebih besar dari 0,60. Suatu konstruk atau variabel dikatakan reliabel jika memberikan nilai Cronbach Alpha $>0,60$. Hasil uji reliabilitas disajikan dalam tabel 3.

Berdasarkan hasil uji reliabilitas di atas, dapat disimpulkan bahwa keseluruhan instrumen pernyataan yang digunakan untuk mengukur variabel-variabel yang dianalisis dalam penelitian ini dinyatakan reliabel. Dapat dilihat dari nilai Cronbach Alpha seluruh variabel yang diterliti lebih besar dari 0,6. 
Tabel 3

Hasil Uji Reliabilitas

\begin{tabular}{llccc}
\hline No & $\quad$ Instrumen Variabel Penelitian & $\begin{array}{c}\text { Nilai } \\
\text { Cronbach's } \\
\text { Alpha }\end{array}$ & $\begin{array}{c}\text { Nilai } \\
\text { Kritis }\end{array}$ & Kesimpulan \\
\hline 1 & Pengelolaan Keuangan Desa (Y) & 0,937 & 0,6 & Reliabel \\
2 & Partisipasi Masyarakat (X1) & 0,753 & 0,6 & Reliabel \\
3 & Transparansi (X2) & 0,803 & 0,6 & Reliabel \\
4 & Akuntabilitas (X3) & 0,827 & 0,6 & Reliabel \\
5 & Kualitas Sumber Daya Manusia (X4) & 0,829 & 0,6 & Reliabel \\
6 & Pemanfaatan Teknologi Informasi (X5) & 0,829 & 0,6 & Reliabel \\
7 & Penerapan Sistem Pengendalian Intern (X6) & 0,925 & 0,6 & Reliabel \\
\hline
\end{tabular}

Sumber: Data Olahan menggunakan SPSS

Berdasarkan hasil uji validitas dan uji reliabilitas yang telah dilakukan, menunjukkan bahwa instrumen pernyataan yang digunakan untuk mengukur keseluruhan variabel yang diteliti dinyatakan valid dan reliabel, sehingga data yang dihasilkan dalam penelitian ini berkualitas dan layak untuk dianalisis lebih lanjut.

\section{Hasil Uji Analisis Regresi Linear Berganda}

Berikut Tabel 4 disajikan agar mengetahui hubungan antara variabel bebas terhadap variabel terikat dalam penelitian ini:

\section{Tabel 4}

Hasil Uji Analisis Linear Berganda

\begin{tabular}{|c|c|c|c|c|c|}
\hline \multirow[b]{2}{*}{ Model } & \multicolumn{2}{|c|}{ Unstandardized Coefficients } & Standardized Coefficients & \multirow[b]{2}{*}{$\mathrm{T}$} & \multirow[b]{2}{*}{ Sig. } \\
\hline & $\mathrm{B}$ & Std. Error & Beta & & \\
\hline 1 (Constant) & 22.726 & 7.727 & & 2.941 & .004 \\
\hline $\mathrm{X} 1$ & .687 & .174 & .228 & 3.937 & .000 \\
\hline $\mathrm{X} 2$ & .592 & 209 & .173 & 2.827 & .005 \\
\hline X3 & -.585 & .285 & -.15 & -2.049 & .043 \\
\hline $\mathrm{X} 4$ & -.455 & .176 & -.182 & -2.584 & .011 \\
\hline X5 & -.468 & 157 & -.176 & -2.983 & .003 \\
\hline X6 & 1.134 & .111 & .866 & 10.243 & .000 \\
\hline
\end{tabular}

a. Dependent Variable: Y

Sumber: Data Olahan menggunakan SPSS

Berdasarkan Tabel 4 dapat diperoleh hasil uji t dan tingkat signifikan antara variabel bebas terhadap variabel terikat dalam penelitian ini:

\section{Hasil Pengujian Hipotesis 1}

Dari tabel 4 dapat dilihat bahwa $\mathrm{t}_{\text {hitung }}>\mathrm{t}$ tabel yaitu 3,937> 1,994 dan signifikansii $0,000<0,05$. Dengan demikian, $\mathrm{H}_{0}$ ditolak dan $\mathbf{H}_{\mathbf{1}}$ diterima. Dapat disimpulkan bahwa Partisipasi Masyarakat berpengaruh terhadap Pengelolaaan Keuangan Desa di desa-desa Kabupaten Kampar. Dengan diterima hipotesis ini membuktikan bahwa partisipasi 
masyarakat merupakan faktor penting dalam pengelolaan keuangan desa. Pengelolaan keuangan desa dengan melibatkan partisipasi masyarakat dapat meningkatkan pelaksanaan pemerintahan desa yang sesuai dengan potensi desa sehingga dapat memenuhi kebutuhan masyarakat, sehingga semakin tinggi partisipasi maka pelaksanaan kegiatan yang menyangkut kebutuhan masyarakat yang merupakan hasil dari pengelolaan dana desa yang baik.

Hal ini sependapat dengan penelitian Medianti (2018) menunjukkan bahwa partisipasi masyrakat berpengaruh terhdap pengelolaan dana desa. Artinya semakin intens partisipasi masyarakat, maka pengelolaan dana desa semakin akuntabel. Penelitian Pratama (2018) menunjukkan bahwa partisipasi berpengaruh dalam pengelolaan dana desa. Namun berbeda dengan penelitian Ultafiah (2017) bahwa keterlibatan masyarakat dalam pelaksanaan tidak selalu menunjukkan bahwa pengelolaan keuangan telah dilakukan dengan baik, begitupun sebaliknya, tidak terlibatnya masyarakat dalam pelaksanaan tidak selalu menunjukkan bahwa pengelolaan keuangan itu buruk.

\section{Hasil Pengujian Hipotesis 2}

Dari tabel 4 dapat dilihat bahwa $\mathrm{t}_{\text {hitung }}>\mathrm{t}_{\text {tabel }}$ yaitu 2,827 $>1,97944$ dan signifikansi $0,005<0,05$. Dengan demikian, $\mathrm{H}_{0}$ ditolak dan $\mathbf{H}_{2}$ diterima. Dapat disimpulkan bahwa Transparansi berpengaruh terhadap Pengelolaan Keuangan Desa di Kabupaten Kampar. Dengan diterima hipotesis ini membuktikan bahwa unsur transparansi diantaranya informatif, keterbukaan, pengungkapan, ketersediaan informasi, keterlibatan masyarakat, keterbukaan proses, dan keterbukaan informasi dapat mempengaruhi pengelolaan keuangan desa yang baik. Sehingga unsur transparansi tersebut mampu mendapatkan kepercayaan dari masyarakat terhadap pemerintah dalam melaksanakan pengelolaan keuangan desa.

Penelitian tentang transparansi sebelumnya pernah diteliti oleh Rosyidi (2018) Transparansi mempunyai pengaruh signifikan terhadap akuntabilitas pemerintah desa dalam pengelolaan alokasi dana desa di Kecamatan Salo. Artinya semakin tinggi tingkat transparansi maka semakin baik pemerintah desa dalam pengelolaan alokasi dana desa. Selanjutnya penelitian dari Ramadan (2019) transparansi berpengaruh terhadap akuntabilitas pengelolaan keuangan desa dan penelitian Pratama (2018) menunjukkan bahwa transparansi berpengaruh dalam pengelolaan dana desa. Namun berbeda dengan penelitian yang dilakukan oleh Sukmawati \& Nurfitriani (2019) menunjukkan Transparansi tidak berpengaruh terhadap pengelolaan keuangan desa di Kabupaten Garut.

\section{Hasil Pengujian Hipotesis 3}

Dari tabel tersebut, dapat dilihat bahwa $\mathrm{t}_{\text {hitung }}<\mathrm{t}$ tabel yaitu $-2.049<1,97944$ dan 
signifikansi 0,043> 0,05. Dengan demikian, $\mathrm{H}_{0}$ ditolak dan $\mathbf{H}_{3}$ diterima. Dapat disimpulkan bahwa akuntabilitas berpngaruh terhadap pengelolaan keuangan desa di Kabupaten Kampar. Akuntabilitas dalam pengelolaan keuangan desa merupakan pertanggungjawaban atas setiap pelaksanaan kegiatan pemerintah dan aparat desa secara tertib kepada masyarakat maupun pemerintah yang diatasnya sesuai dengan perundang-undangan. Akuntabilitas dalam pengelolaan keuangan desa yang baik secara teknik dan administrasi sesuai dengan peraturan yang berlaku dapat meningkatkan pembangunan dan pemberdayaan masyarakat.

Hasil dari penelitian ini sejalan dengan Nafidah \& Suryaningtyas (2016) dan Dura (2016) bahwa akuntabilitas berpengaruh terhadap pengelolaan keuangan desa. Namum, berbeda dengan penelitian Riyanto (2018) menunjukkan bahwa dimulai dari proses pelaksanaan sampai dengan pencapaian hasilnya dapat dipertanggungjawab kepada seluruh pihak pemerintah desa namun belum dapat dipertanggungjawabkan kepada seluruh masyarakat desa.

\section{Hasil Pengujian Hipotesis 4}

Dari table 4 dapat dilihat bahwa $\mathrm{t}_{\text {hitung }}>\mathrm{t}$ tabel yaitu $-2.584>1,97944$ dan signifikansi $0,011<0,05$. Dengan demikian, $\mathrm{H}_{0}$ ditolak dan $\mathbf{H}_{\mathbf{4}}$ diterima. Dapat disimpulkan bahwa Kualitas Sumber Daya Manusia berpengaruh Terhadap Pengelolaan Keuangan Desa di Kabupaten Kampar. Sumber daya manusia mempunyai pengaruh yang besar dalam pengelolaan keuangan desa hal ini karena didalam pemerintahan desa sumber daya manusia yang menjalankan dan menggerakkannya oleh karena itu, sumber daya manusia tersebut harus memiliki kemampuan, pengetahuan dan prilaku yang baik. Seperti yang dikatakan (Sembiring, 2013) sumber daya yang berkualitas harus didukung dengan latar belakang pendidikan akuntansi, sering mengikuti pendidikan, dan mempunyai pengalaman di bidang keuangan. Sehingga pemerintah desa mampu menyajikan laporan keuangan yang berkualitas sebagai bentuk pertanggungjawaban kinerja kepada masyarakat desa.

Dilihat dari penelitian yang dilakukan oleh Wardani \& Andriyani (2017) menunjukkan bahwa Kualitas Sumber Daya Manusia berpengaruh positif secara signifikan terhadap Keandalan Pelaporan Keuangan Pemerintahan Desa. Akan tetapi berbeda dengan penelitian Arfianti (2011) yang menyimpulkan bahwa kualitas SDM tidak berpengaruh terhadap akuntabilitas pengelolaan keuangan desa.

\section{Hasil Pengujian Hipotesis 5}

Dari tabel 4 dapat dilihat bahwa $\mathrm{t}_{\text {hitung }}>\mathrm{t}_{\text {tabel }}$ yaitu $-2.983>1,97944$ dan signifikansi $0,003<0,05$. Dengan demikian, $\mathrm{H}_{0}$ ditolak dan $\mathbf{H}_{5}$ diterima. Dapat disimpulkan 
bahwa Pemanfaatan Teknologi Informasi berpengaruh terhadap Pengelolaan Keuangan Desa. Pemanfaatan teknologi informasi sangat berpengaruh dalam pengelolaan keuangan desa, karena teknologi informasi adalah suatu teknologi yang digunakan untuk mengolah data, termasuk memproses, mendapatkan, menyusun, menyimpan, memanipulasi data untuk menghasilkan informasi yang berkualitas. Oleh karena itu, pengelolaan keuangan desa akan menjadi lebih baik dan menghasilkan informasi yang relevan, akurat, dan tepat waktu yang digunakan untuk keperluan pemerintahan desa dan masyarakat.

Yosefrinaldi (2013) mengatakan bahwa semakin besar pemanfaatan teknologi informasi maka kualitas laporan keuangan yang dihasilkan pemerintah akan semakin baik pula. Selain itu (Aulia, 2018) melakukan penelitian yang menunjukkan bahwa pemanfaatan teknologi informasi berpengaruh positif terhadap akuntabilitas pengelolaan keuangan desa dan Pramurdiarta (2015) menyatakan pemanfaatan teknologi informasi aka sangat membantu sumber daya manusia dalan proses akuntansi dan dapat mengurangi kesalahan dalam pemrosesan data, sehingga dapat menghasilkan laporan keuangan yang andal. Namun berbeda dengan penelitian yang dilakukan Wardani \& Andriyani (2017) menunjukkan bahwa Kualitas Sumber Daya Manusia tidak berpengaruh terhadap Keandalan Pelaporan Keuangan Pemerintahan Desa.

\section{Hasil Pengujian Hipotesis 6}

Dari tabel tersebut, dapat dilihat bahwa $\mathrm{t}_{\text {hitung }}>\mathrm{t}$ tabel yaitu $10.243>1,97944$ dan signifikansi 0,000 < 0,05. Dengan demikian, $\mathrm{H}_{0}$ ditolak dan $\mathbf{H}_{\mathbf{6}}$ diterima. Dapat disimpulkan bahwa Penerapan Sistem Pengendalian Intern berpengaruh terhadap Pengelolaan Keuangan Desa Kabupaten Kampar. Sistem pengendalian intern sangat berpengaruh dalam pengelolaan keuangan desa karena bertujuan untuk memberi keyakinan yang memadai tentang laporan keuangan yang dapat diandalkan. Dengan adanya sistem pengendalian intern yang baik diharapkan mampu mencegah atau mendeteksi terjadinya kesalahan dalam proses akuntansi sehingga proses akuntansi dapat dikerjakan dengan cepat dan tepat serta dapat meyakinkan masyarakat desa tentang keakuratan, keandalan, dan ketepatwaktuan laporan keuangan pemerintah desa. Hal ini dibuktikan oleh penelitian yang dilakukan Sembiring (2013) yang menyatakan bahwa sistem pengendalian intern berpengaruh signifikan terhada pelaporan keuangan pemerintah desa.

Selain itu, dalam penelitian Marlinawati \& Wardani (2018) menunjukkan bahwa sistem pengendalian intern berpengaruh positif secara signifikan terhadap keandalan pelaporan keuangan pemerintah desa. Penelitian yang dilakukan oleh Widyatama et al (2017) 
juga menunjukkan bahwa Sistem Pengendalian Aparatur dari Pemerintah Desa secara signifikan mempengaruhi Akuntabilitas Pengelolaan Keuangan lokasi Dana Desa (ADD), akan tetapi penelitian imi tidak sejalan dengan penelitian Karmila (2012) yang menyimpulkan bahwa pengendalian intern tidak mempunyai pengaruh secara signifikan terhadap keterandalan pelaporan keuangan pemerintah.

\section{SIMPULAN}

Hasil dari penelitian ini dapat disimpulkan bahwa partisipasi masyarakat, transparansi, akuntabilitas, kualitas sumber daya manusia, pemanfaatan teknologi informasi dan penerapan sistem pengendalian intern berpengaruh terhadap pengelolaan keuangan desa di kabupaten Kampar. Dengan menunjukkan rata-rata analisis deskriptif lebih besar daripada standar deviasinya. Maka dari itu, pengelolaan keuangan desa dipengaruhi oleh partisipasi masyarakat, transparansi, akuntabilitas, kualitas sumber daya manusia, pemanfaatan teknologi informasi dan penerapan sistem pengendalian intern.

Penelitian ini memiliki keterbatasan yaitu hanya dilakukan pada wilayah kabupaten Kampar serta hanya mengandalkan kuesioner dalam pengumpulan data. Oleh sebab itu disarankan penelitian selanjutnya untuk memperluas wilayah penelitian serta dapat melakukan teknik wawancara untuk memperkuat hasil penelitian. Penelitian ini juga menggunakan variabel independen sebagai penyebab faktor yang mempengaruhi pengelolaan keuangan desa serta analisis yang menggunakan regressi liner berganda. Penelitian selanjutnya dapat menggunakan variabel moderasi ataupun mediasi untuk melihat pengaruh pengelolaan keuangan desa dengan menggunakan teknik analisis Struktural Wquation Model (SEM).

Berhasilnya hipotesis bisa menjadi masukan bagi pemerintah untuk mengevaluasi Pengelolaan Keuangan Desa yang telah ada untuk meningkatkan kinerja perangkat desa, sitem akuntansi keuangan desa dan kompetensi sumber daya manusia perangkat desa Kabupaten Kampar agar lebih efektif.

\section{REFERENSI}

Arfianti, D. (2011). Analisis Faktor-Faktor yang Mempengaruhi Nilai Informasi Pelaporan Keuangan Pemerintah Daerah (Studi pada Satuan Kerja Perangkat Daerah di Kabupaten Batang). Skripsi, 1(2011), 1-91.

Aulia, P. (2018). Pengaruh Kompetensi Aparat Pengelola Dana Desa, Komitmen Organisasi Pemerintah Desa, Pemanfaatan Teknologi Informasi, dan Partisipasi Masyarakat Terhadap Akuntabilitas Pengelolaan Dana Desa di Kabupaten 50 Kota (Studi Empiris Pada Kecamatan Harau. Jurnal Online Mahasiswa. Fakultas Ekonomi dan Bisnis, 


\section{Universitas Riau, 1 .}

Dura, J. (2016). Pengaruh Akuntabilitas Pengelolaan Keuangan Alokasi Dana Desa, Kebijakan Desa dan Kelembagaan Desa terhadap Kesejahteraan Masyarakat (Studi Kasus pada Desa Gubuklakah Kecamatan Poncokusumo Kabupaten Malang). Jurnal JIBEKA, 10.

Hartati, W. (2020). Analisis Flypaper Effect Pada Belanja Desa di Kabupaten Siak. Current Jurnal Kajian Akuntansi Dan Bisnis Terkini, 1, 2.

Karmila. (2012). Pengaruh Kapasitas Sumber Daya Manusia Pemanfaatan Teknologi Informasi, dan Pengendalian Intern Terhadap Keterandalan Pelaporan Keuangan Pemerintah Daerah (Studi Pada Pemerintah Provinsi Riau). E-Jurnal, Universitas Riau.

Machfiroh, I. S. (2019). Akuntabilitas Pengelolaan Keuangan Desa di Desa Benua Tengah. Jurnal Riset Akuntansi Politala, 1(1), 14. https://doi.org/10.34128/jra.v1i1.5

Mahmudi. (2015). Manajemen Kinerja Sektor Publik. Yogyakarta: UPP STIM YKPN.

Manopo, W. F. (2013). Faktor-faktor yang Mempengaruhi Struktur Modal Perbankan yang Go Public di BEI Tahun 2008-2010. Jurnal Riset Ekonomi, Manajemen, Bisnis dan Akuntansi, 1(3), 653-663.

Mardiasmo. (2009). Akuntansi Sektor Publik. Yogyakarta: Andi Offset.

Marlinawati, M., \& Wardani, D. K. (2018). Pengaruh Kualitas Sumber Daya Manusia, Pemanfaatan Teknologi Informasi, dan Sistem Pengendalian Intern Terhadap Ketepatwaktuan Pelaporan Keuangan Pemerintah Desa. Kajian Bisnis STIE Widya Wiwaha, 26(2), 131-143. https://doi.org/10.32477/jkb.v26i2.274

Medianti, L. (2018). Pengaruh Kompetensi Aparatur, Komitmen Organisasi, dan Partisipasi Masyarakat Terhadap Pengelolaan Dana Desa (Studi Empiris pada Desa-Desa di Kabupaten Bintan). Jurnal Online Mahasiswa, Fakultas Ekonomi dan Bisnis Universitas Riau, 1 .

Nafidah, L. N., \& Suryaningtyas, M. (2016). Akuntabilitas Pengelolaan Alokasi Dana Desa Dalam Upaya Meningkatkan Pembangunan dan Pemberdayaan Masyarakat. BISNIS: Jurnal Bisnis Dan Manajemen Islam, 3(1), 214. https://doi.org/10.21043/bisnis.v3i1.1480

Pasolong, H. (2013). Teori Administrasi Publik. Bandung: Alfabeta.

Peraturan Pemerintah Nomor 60 Tahun 2014 tentang dana desa yang bersumber dari APBN, (2014).

Pramurdiarta, R. (2015). Pengaruh Kompetensi Sumber Daya Manusia, Pemanfaatan Teknologi Informasi, dan Sistem Pengendalian Intern Terhadap Nilai Informasi Pelaporan Keuangan Entitas Akuntansi Pemerintah Daerah (Studi Persepsi Pegawai SKPD di Kabupaten Batang dan Kabupaten Kendal). Diponegoro Journal of Accounting, 4(3), 641-654. 
Pratama, R. E. (2018). Akuntabilitas, Transparansi, dan Partisipasi Dalam Pengelolaan Dana Desa (Studi Kasus Pada Desa di Kecamatan Natar Kabupaten Lampung Selatan). Universitas Lampung.

Ramadan, S. W. (2019). Pengaruh Kualitas Sumber Daya Manusia, Transparansi dan Pemanfaatan Teknologi Terhadap Akuntabilitas Pengelolaan Keuangan Desa (Studi Empiris pada Pemerintah Desa di Kecamatan Bendosari, Polokarto, dan Mojolaban di Kabupaten Sukoharjo). Fakultas Ekonomi dan Bisnis. Universitas Muhammadiyah. Surakarta.

Riyanto, T. (2018). Akuntabilitas Finansial Dalam Pengelolaan Alokasi Dana Desa (ADD) di Kantor Desa Perangat Selatan Kecamatan Marangkayu Kabupaten Kutai Kartanegara. Journal Administrasi Negara, 1(1), 119-130.

Rosyidi, M. (2018). Pengaruh Transparansi, Kompetensi dan Sistem Pengendalian Internal Terhadap Akuntabilitas Pemerintah Desa Dalam Pengelolaan Alokasi Dana Desa di Seluruh Desa di Kecamatan Salo Kabupaten Kampar. Jurnal Oline Mahasiswa, Fakultas Ekonomi dan Bisnis, Universitas Riau, 1.

Rusman. (2011). Pembelajaran Berbasis Teknologi Informasi dan Komunikasi. Rajawali pers. cetakan-1.

Sembiring, F. L. (2013). Pengaruh Kualitas Sumber Daya Manusia, Pemanfaatan Teknologi Informasi, dan Pengendalian Intern Akuntansi Terhadap Nilai Informasi Pelaporan Keuangan Pemerintah Daerah (Studi Pada Satuan Kerja Perangkat Daerah di Kabupaten Pasaman Barat). Jurnal Elektronik Universitas Negeri Padang.

Sugista, R. A. (2017). Pengaruh Transpansi, Akuntabilitas, dan Partisipasi Masyarakat Dalam Pengelolaan Keuangan Desa Terhadap Pembangunan Desa. Jurnal Sosiologi, 01, 18.

Sukmawati, F., \& Nurfitriani, A. (2019). Pengaruh Transparansi dan Akuntabilitas terhadap Pengelolaan Keuangan Desa (Studi Pada Pemerintah Desa di Kabupaten Garut). Jurnal Ilmiah Bisnis, Pasar Modal, dan UMKM, 2(1), 52-66.

Taufik, T. (2019). The Effect of Internal Control System Implementation in Realizing Good Governance and Its Impact on Fraud Prevention. International Journal of Scientific and Technology Research, 8(9), 2159-2165.

Ultafiah, W. (2017). Pengaruh akuntabilitas, transparansi dan partisipasi terhadap pengelolaan dana desa untuk mewujudkan Good Governance Pada Desa Di Kecamatan Merapi Barat Kabupaten Lahat. Skripsi. Universitas Muhammadiyah Palembang.

Wardani, D. K., \& Andriyani, I. (2017). Pengaruh Kualitas Sumber Daya Manusia, Pemanfaatan Teknologi Informasi, dan Sistem Pengendalian Intern Terhadap Keandalan Pelaporan Keuangan Pemerintahan Desa di Kabupaten Klaten. Jurnal Akuntansi, 5(2), 88-98. https://doi.org/10.24964/ja.v5i2.270

Widyatama, A., Novita, L., \& Diarespati, D. (2017). Pengaruh Kompetensi dan Sistem Pengendalian Internal Terhadap Akuntabilitas Pemerintah Desa Dalam Mengelola Alokasi Dana Desa (ADD). Berkala Akuntansi dan Keuangan Indonesia, 2(2), 1-20. https://doi.org/10.20473/baki.v2i2.4762 
www.dpjk.kemenkeu.go.id

Yosefrinaldi. (2013). Pengaruh Kapasitas Sumber Daya Manusia dan Pemanfaatan Teknologi Informasi Terhadap Kualitas Laporan Keuangan Pemerintah Daerah dengan Variabel Intervening Sistem Pengendalian Intern Pemerintah (Studi Empiris Pada DPKAD SeSumatera Barat). Jurnal Akuntansi, 1(1), 1-24. 